\title{
Temperature changes and marine fish species (Epinephelus coioides and Sparus aurata): role of oxidative stress biomarkers in toxicological food studies
}

\author{
Giulia Guerriero ${ }^{1,2 *}$, Samah M. Bassem², Wagdy K. B. Khalii ${ }^{3}$, Tarek A.Temraz ${ }^{4}$, Gaetano Ciarcia1, \\ Fagr Kh. Abdel-Gawad²*
}

${ }^{1}$ EClab, Department of Biology, University of Naples, Federico II, Naples, Italy, ${ }^{2}$ Department of Water Pollution, Centre of Excellence for Advanced Science Research, National Research Centre, Dokki, Giza, Egypt, ${ }^{3}$ Department of Cell Biology, National Research Centre, Dokki, Giza, Egypt, ${ }^{4}$ Department of Marine Science, Faculty of Science, Suez Canal University, Ismailia, Egypt

\section{A B S T R A C T}

\begin{abstract}
The increase of seawater temperature as a result of global climate variation elucidates a major challenge for marine organisms survival in addition to consumers safety. Spotted grouper (Epinephelus coioides) and Seabream (Sparus aurata) were collected in water with different temperature variations at Suez Canal and Alexandria (Suez and Abu Qir bay) in Egypt with the aim to assess expression levels of heat shock proteins such as HSP47, HSP70 and HSP90 genes in addition to antioxidants value through enzymes activity: Glutathione-S-Transferase (GST) and Glutathione Peroxidase (GPx). Research results revealed that expression of the HSP47, HSP70a and HSP9O genes increased in marine fishes tissues collected from Suez Canal, with higher water temperature $\left(23: 28^{\circ} \mathrm{C}\right)$, compared with those collected from Alexandria $\left(19: 24^{\circ} \mathrm{C}\right)$ whereas the content of GPx and GST decreased. Our results show alteration of the marker examined suggesting that the increase of heat shock protein genes expression levels of fish collected from Suez Canal might be exposed mainly to thermal oxidative stress response more than those collect from Alexandria. The increase of heat shock protein-related genes expression could be considered as a factor in prohibiting the heat shock transcription factor that may lead to stimulation of heat-inducible genes in addition to heat acclimation. Thus, warming of water is also likely to alter the composition and abundance of food resources, e.g. fish muscles, available to higher trophic level consumers.
\end{abstract}

Keywords: Antioxidant; Heat Shock Proteins; Epinephelus coioides; Sparus aurata; Gene expression.

\section{INTRODUCTION}

Variation in temperature range is being an environmental stress factor which affects cellular homeostasis and results in growth retardation and also affects reproduction and leads to variations in antioxidants content of seafood (Guerriero et al., 2002; Dong et al., 2008; Wentworth et al., 2018). The heat shock response (HSR) is known to be a possible cellular technique which may affect the upper thermal tolerance of any organism (Lee et al., 2016). The HSR is recognized by the ability to synthesize many protein types, Heat Shock Proteins (HSPs), establishing and refolding proteins in addition to leading formerly denatured proteins to the proteolytic machinery (Tomanek, 2010; Roberts et al., 2010; Wang et al., 2015; Zunino et al., 2016). In contrary to the HSR, that gave rise to transient stimulation of HSPs as a result of any unexpected heat shock, acclimation reaction refers to physiological variations that presented if the organism suffered from temperature changes for a long period (Lewis et al., 2016). The HSR was investigated in many studies covering model and non-model organisms (Buckley and Hofmann, 2002; Muzio et al., 2016). It was noted that the heat shock factor 1 is able to mediate up-regulation of HSPs like HSP70 and HSP90 acts a critical role in survivability providing to the organisms subjected to heat stress (Fangue et al., 2006; Tomanek and Somero, 2002; Copat et al., 2012). However, cellular HSR differs among species based on variable temperature rates in which they live in (Tomanek, 2010). Organisms that inhabit fluctuated thermal environments,

\footnotetext{
${ }^{*}$ Corresponding authors:

Fagr Kh. Abdel-Gawad, Department of Water Pollution, Centre of Excellence for Advanced Science Research, National 6 Research Centre, Dokki, Giza, Egypt. E-mail: fagrabdlgawad@gmail.com Giulia Guerriero, EClab, Department of Biology, University of Naples, Federico II, Naples, Italy. E-mail: giulia.guerriero@unina.it
}

Received: 11 January 2018; Accepted: 20 March 2018 
such as the intertidal area $\left(<20^{\circ} \mathrm{C}\right)$, produce the hSR considerably. Such species are found close to their thermal borders that the maximum temperatures they can manage an HSR is lightly higher than the extreme limits based on regular basis, then any increase in temperature may lead to their evanescence (Tomanek, 2010). However, in contrast, the species inhabiting moderate variations in temperature, such as the sub-tidal area, promote the HSR at temperature limits higher than those they could manage in environment. Also, both of duration and magnitude of heat stress influence expression dynamics of HSP genes (Tomanek, 2010). Possible hazards of climate change on some fish species was studied with killifish (Austrofundulus limnaeus) after exposure for for 14.5 days to both constant temperatures $\left(20,26\right.$ or $\left.37^{\circ} \mathrm{C}\right)$ and also daily variations (20 to $\left.37^{\circ} \mathrm{C}\right)$.

Results indicated that fish showed great response to different temperature limits, that higher HSPs (HSP70 and HSP90) were up-regulated during stable elevatedtemperature level exposure time (Podrabsky and Somero, 2004; Piscopo et al., 2018; Somero, 2010).

Since the fish represents a pivotal role in human diet, very important is to detect the effect of temperature alteration that can induce overexpression with reduction of antioxidants at same time as physiological defence and nutritional factor for the consumers. To investigate the potential alteration operated by the temperature on fish filet of Epinephelus coioides and Sparus aurata, marine fish widely known for human feeding, value of the HSPs gene expression and antioxidants activity for the same species obtained from fish of Suez Gulf are compared with those obtained for samples of fish of Alexandria.

\section{MATERIALS AND METHODS}

\section{Chemicals}

The used reagents for qRT-PCR: kits, chemicals, and primers were bought from Invitrogen (Germany). All chemicals and reagents were from the highest available purity.

\section{Fish sampling}

Fish sampling was collected in the period between April to August of 2017 from different locations at Suez Canal

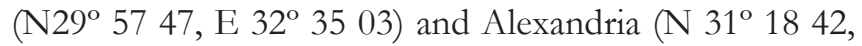
E $\left.30^{\circ} 0241\right)$ with water temperature between $\left(19: 24^{\circ} \mathrm{C}\right.$; $23: 28^{\circ} \mathrm{C}$ ) respectively. The samples were transported in icebox and analysis was performed as soon as possible. Then, liver and gills tissues of fish sampled from different sites were kept in liquid nitrogen till biochemical and molecular biological analyses.

\section{Gene expression analysis Total RNA Isolation}

We used TRIzol® reagent (cat\#15596-026, Invitrogen, Germany) for total RNA extraction from liver and gills tissues of Spotted grouper (Epinephelus coioides) and Seabream (Sparus aurata) referring to the instructions of manufacturer after some modifications. The extracted pellet of RNA was then resolved in Diethyl-pyro-carbonate (DEPC) treated water and then preserved at $-80^{\circ} \mathrm{C}$. The extracted total RNA was then dealt by 1 unit of RQ1 RNAs free DNAs (Invitrogen, Germany) to digest residues of DNA and re-suspended in DEPC-treated water and quantified at $260 \mathrm{~nm}$ photospectrometrically. Total RNA purity was determined by the $260 / 280 \mathrm{~nm}$ ratio that was between 1.8 and 2.1. Moreover, integrity was confirmed using Ethidium bromide stain analysis of $28 \mathrm{~S}$ and $18 \mathrm{~S}$ bands by formaldehyde-comprising agarose gel electrophoresis. Aliquots were then used immediately in experiments for reverse transcription (RT), otherwise, they were preserved at $-80^{\circ} \mathrm{C}$.

\section{Reverse transcription (RT) reaction}

The complete Poly (A) ${ }^{+}$RNA isolated from tissues of Spotted grouper and Seabream was transferred to cDNA in a total volume of $20 \mu \mathrm{l}$ by using revert aid first strand cDNA synthesis kit (Fermentas, Germany). Total RNA $(5 \mu \mathrm{g})$ was used in a master mix (MM). The MM contained reverse transcription (RT) buffer (10 mM Tris-HCl; $\mathrm{pH}$ 8.3; $50 \mathrm{mM} \mathrm{KCl}$ ), $50 \mathrm{mM} \mathrm{MgCl}, 10 \mathrm{x}, 10 \mathrm{mM}$ of each dNTP, $20 \mathrm{IU}$ ribonuclease inhibitor $(50 \mathrm{kD}$ a recombinant enzyme to inhibit RNase activity), $50 \mu \mathrm{M}$ oligo-dT primer and $50 \mathrm{IU}$ MuLV reverse transcriptase. The sample mixture was centrifuged at $1000 \mathrm{~g}$ for $30 \mathrm{sec}$ and transferred to precede thermocycler. The RT reaction was carried out for $10 \mathrm{~min}$ at $25^{\circ} \mathrm{C}$, followed by $1 \mathrm{~h}$ at $42^{\circ} \mathrm{C}$, and terminated by a denaturation step for $5 \mathrm{~min}$ at $99^{\circ} \mathrm{C}$. Afterwards, the reaction tubes with RT preparations were flash-cooled in ice chamber still being used in cDNA amplification using real time polymerase chain reaction (RT-PCR).

\section{Semi-quantitative real-time- PCR (qRT-PCR)}

A step one real-time PCR system (Applied Biosystem, USA, 2000) was applied to detect cDNA copy number of Spotted grouper and Seabream. To constitute PCR reaction, a final volume of $25 \mathrm{~mL}$ of was prepared as follows: $0.5 \mathrm{ml}$ of $0.2 \mathrm{mM}$ forward and reverse primers, $12.5 \mathrm{ml}$ of SYBR ${ }^{\circledR}$ green (Takara, Biotech. Co. Ltd.), $6.5 \mathrm{~mL}$ DNA-RNA free water, and finally $2.5 \mathrm{ml}$ of synthesized cDNA. The cDNA was replicated by using reaction program of 3 steps. In the first step, PCR tubes were incubated at $95^{\circ} \mathrm{C}$ for $3 \mathrm{~min}$. In the second step, reaction program is comprised of 50 cycles. Each cycle consisted of 3 sub-steps: (a) $15 \mathrm{sec}$ at $95^{\circ} \mathrm{C}$; (b) $30 \mathrm{sec}$ at $60^{\circ} \mathrm{C}$; and (c) $30 \mathrm{sec}$ at $72^{\circ} \mathrm{C}$. in the third step reaction program consisted of 71 cycles. The first 
cycle started at $60^{\circ} \mathrm{C}$ for $10 \mathrm{sec}$ and then the other cycles increased gradually by $0.5^{\circ} \mathrm{C}$ every $10 \mathrm{sec}$ up to $95.0^{\circ} \mathrm{C}$. A melting curve of the reaction was done for each qRTPCR termination step at $95.0^{\circ} \mathrm{C}$ to determine quality of used primers. For verification of the qRT-PCR reaction that wasn't contaminated, PCR tubes with no template control were used. The primer sequences were listed in Table 1 (Abdel-Gawad and Khalil, 2013 and Chen et al., 2010). Relative quantification of target genes to the reference ( $\beta$-Actin) was evaluated by applying the $2{ }^{-\Delta \Delta C T}$ technique (Livak and Schmittgen 2001).

\section{Glutathione peroxidase and glutathione-S-transferase activities}

The activity of glutathione peroxidase (GPx) was determined by following the rate of NADPH oxidation at $340 \mathrm{~nm}$ by coupled reaction with glutathione reductase (Puerto et al., 2011; Habig et al. (1974).

\section{Statistical analysis}

Data were analyzed by using one-way analysis of variance ANOVA and significance of differences among means was tested by applying Duncan's multiple range test $(\mathrm{P}<0.05)$. The software used in data analysis was SAS, version 9.1 (Statsoft Inc., Tulsa, USA, 2013). Values were then expressed as means \pm standard deviation.

\section{RESULTS}

\section{Expression of heat shock protein genes}

The expression levels of heat shock protein genes (HSP47, HSP70 and HSP90), as stress protein genes in liver and gills of Spotted grouper and Seabream fish, are summarized in Fig. 1-3.The results showed that the expression levels of all heat shock protein genes were higher in gills tissues than liver tissues.

Moreover, the heat shock protein genes expression levels were up-regulated in Spotted grouper and Seabream collected from Suez Canal compared with those collected from Alexandria (Figs. 1-3). Also, the results revealed that expression levels of HSP47 gene reached their highest levels when compared with expression levels of HSP70 and HSP90 genes. Similar findings were obtained in results of the real time-PCR assay when performed for each sample isolated from different sites throughout sampling period.

\section{Activity levels of Glutathione Peroxidase and Glutathione-S-Transferase}

Results of enzymes activity were presented in Fig. 4, 5. The obtained results showed that activity levels of antioxidant enzymes GPx and GST decreased significantly $(\mathrm{P}<0.05)$ in gills tissues when compared with liver tissues. Moreover, activity levels of GPx and GST decreased in Spotted grouper and Seabream sampled from Suez Canal when compared with those sampled from Alexandria (Figs. 4 and 5).

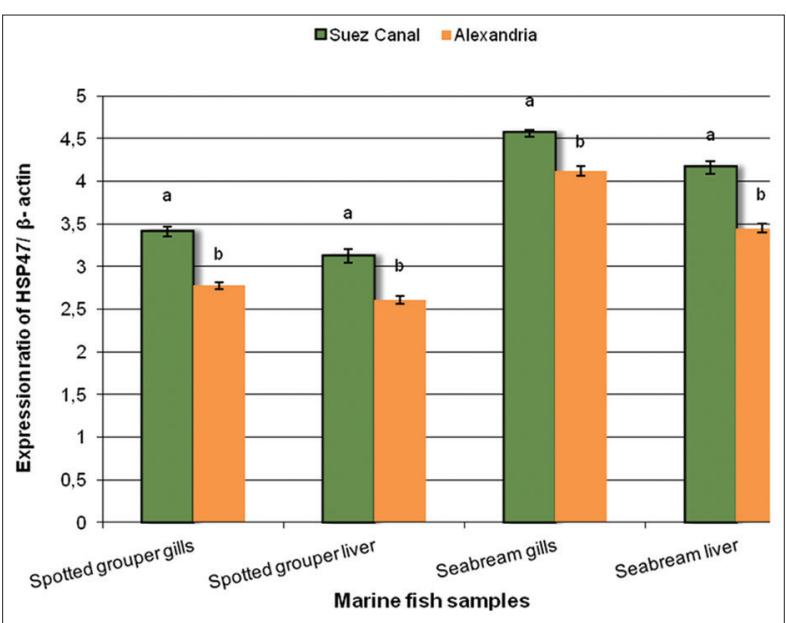

Fig 1. RTqPCR expression of HSP47 gene in the gills and liver tissues of spotted grouper and Seabream sampled from April to August, 2017. a, b: Within each column, means superscripts with different letters are significantly different $(P<0.05)$.

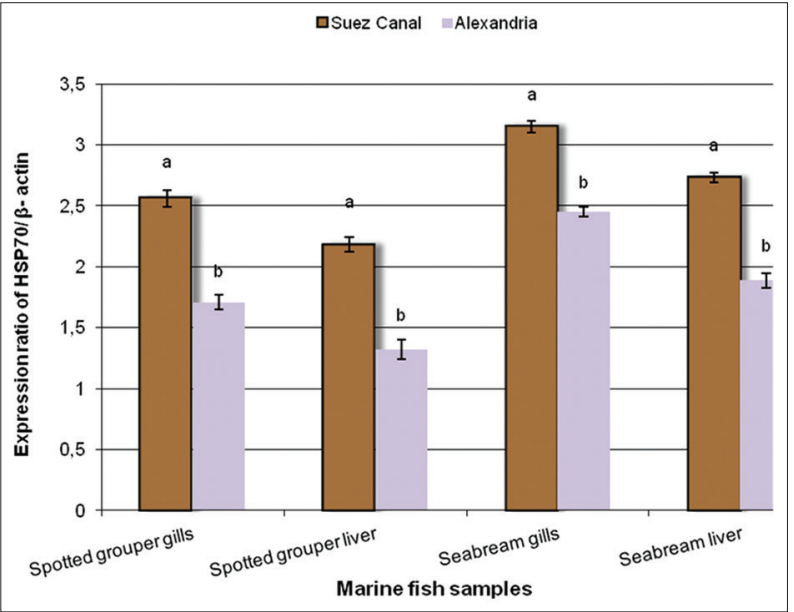

Fig 2. RTqPCR expression of HSP70 gene in the gills and liver tissues of Spotted grouper and seabream sampled from April to August, 2017. a, b: Within each column, means superscripts with different letters are significantly different $(P<0.05)$.

Table 1: Primers sequences used for RT-PCR

\begin{tabular}{ll} 
Gene & Primer sequence (5'-3') \\
\hline Hsp70 & F: CGG GAG TTG TAG CGA TGA GA \\
& R: CTT CCT AAA TAG CAC TGA GCC ATA A \\
Hsp90 & F: ATG CCT GAA GAA ATG CGC CAA GAG GAG \\
& R: CCA ATG GGC TCA CCG TTG TCG ACT CTG \\
Hsp47 & F: CCA GGA AAT GGC ACA TGT AT \\
& R: TAT AAG CAT GCT GTC GGG TC \\
$\beta$-Actin & F: TGG GGC AGT ATG GCT TGT ATG \\
& R: CTC TGG CAC CCT AAT CAC CTC T \\
\hline
\end{tabular}

${ }^{a} \mathrm{~F}$ : forward primer; R: reverse primer. Tm: temperature 


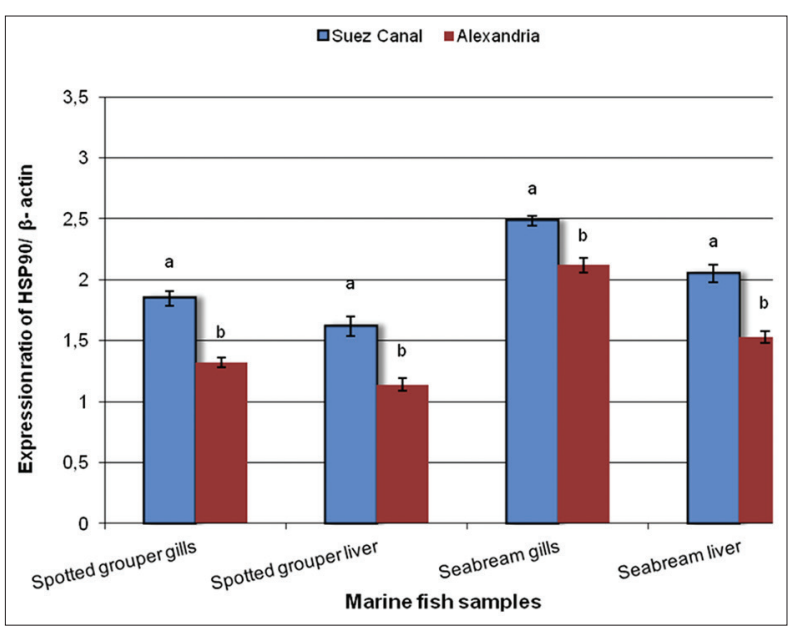

Fig 3. RTqPCR expression of HSP90 gene in the gills and liver tissues of Spotted grouper and Seabream sampled from April to August, 2017. a, b: Within each column, means superscripts with different letters are significantly different $(P<0.05)$.

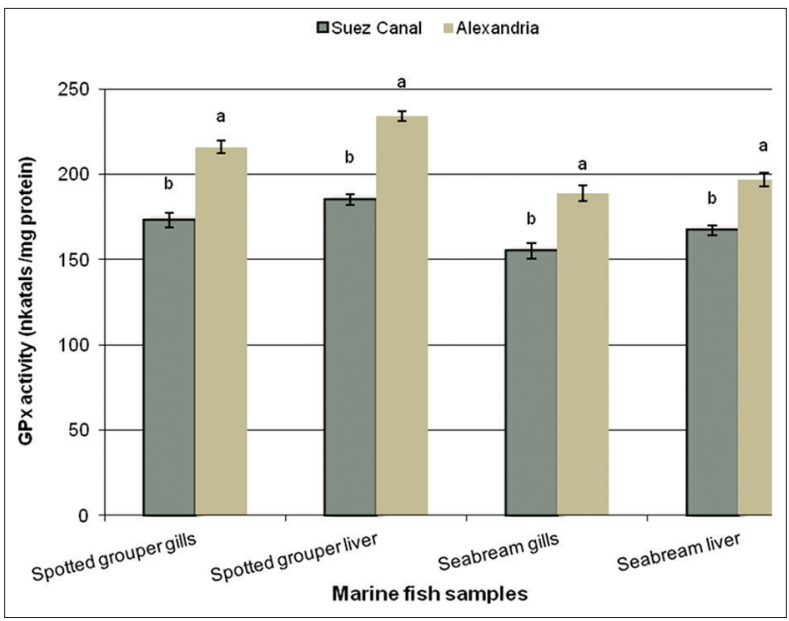

Fig 4. Glutathione Peroxidase (GPx) activity in the gills and liver tissues of Spotted grouper and Seabream sampled from April to August, 2017. a, b: Within each column, means superscripts with different letters are significantly different $(P<0.05)$.

\section{DISCUSSION}

It is well known that fish response to different stress factors, either heat or pollution, is done through eliciting a general physiological stress response which may involve proteins and stress hormones (Iwama and Vijayan, 1999). The major cellular response in both vertebrates and invertebrates against any stressor is the expression of heat shock proteins. They are known by their ability to support the folding of nascent polypeptides, arrange the repair and degradation of denatured proteins and also prohibit irreversible protein accumulation (Haslbeck and Vierling, 2015, Piscopo et al., 2018).

The following research study revealed the potential alteration in HSP gene including HSP47, HSP70 and

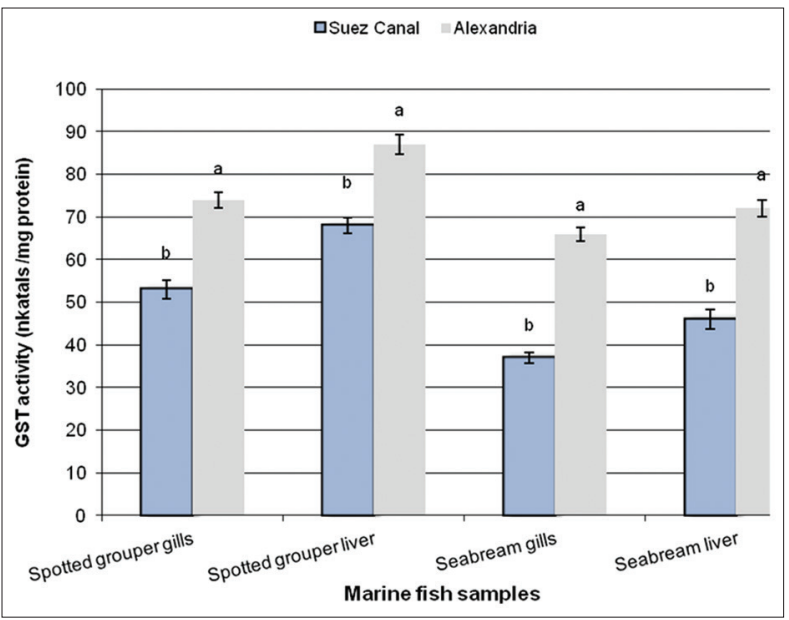

Fig 5. Glutathione-S-Transferase (GST) activity in the gills and liver tissues of Spotted grouper and Seabream sampled from April to August, 2017. a, b: Within each column, means superscripts with different letters are significantly different $(P<0.05)$.

HSP90 as well as antioxidant enzyme activities during the hot summer in Egypt. The results showed that the expression levels of all heat shock protein genes were up-regulated in Spotted grouper and Seabream collected from Suez Canal compared with those collected from Alexandria. During the warm and hot summer, the water quality is influenced due to different changes in the water and sediments as physicochemical profile (Mahanty et al., 2017). The water contents of phosphate, nitrate and also $\mathrm{pH}$ varied greatly and affect fish health and survival (Guerriero et al., 2002). Furthermore, as the hot spring waters were known to be rich in trace elements that may act as environmental stressors (Reddy et al., 2013). Oxidative stress, as known, can be detected by different approach using morphological, ultrastructural, immunoreactivity, chemical, biochemical and molecular approach (Scalici et al., 2017; Bartiromo et al., 2013; Guerriero et al., 2005; Guerriero, 2017ab; Pecoraro et al., 2017; Pecoraro et al., 2018). Variation in expression levels of HSP genes could be expected as a result of water physicochemical parameters alteration in Suez Canal and Alexandria, even though water quality wasn't analyzed. To overcome such point, more research dealing with mesocosm, changes of $\mathrm{pH}$, phosphate and nitrate is going on. The results of the present study exhibited that the expression levels of all heat shock protein genes were up-regulated in Spotted grouper and Seabream collected from Suez Canal compared with those collected from Alexandria. These results indicating that the physicochemical properties of water in Suez Canal are possibly changed as environmental stressors affecting the expression of HSP genes. The present study showed that the expression levels of HSP47, HSP70 and HSP90 were overexpressed in Spotted Grouper and Sea bream collected from Suez Canal compared with those collected from Alexandria. During the thermal stress, HSP90 is 
known to be one of the most commonly expressed hopes that protects the organism cells through reacting with some co-chaperones (Fangue et al., 2006). Moreover, it is included in substrate discrimination and also folding of the improperly folded proteins (Soroka and Buchner, 2012). During thermal adaptation in pathogenic yeast, HSP90 was reported to Rochester transcriptional regulation by HSF1 (Leach et al., 2012). It was found that HSP90 is a suitable biomarker of thermal stress in loggerhead turtle embryonic samples (Tedeschi et al., 2015). The samples of Garra rufa collected from Kangal hot spring, Turkey suffered from thermal stress revealed up-regulation of HSP90 genes (Oksala et al., 2014). So, the results obtained in our research represented in up-regulation of the HSP90 in fish samples collected from Suez Canal in the hot season is considered as indicator of some important functions acted by HSP gene. The HSP70 family genes were found in many organisms, they also prohibit accumulation of polypeptides and assist in refolding of proteins subjected to damage as a result of thermal stress (Kregel, 2002). The family genes of HSP70 include two forms: $73 \mathrm{kDa}$ protein (HSC70) and the stress-inducible protein (HSP70) (Barnes et al., 2001) and we used in our research the most likely inducible one, HSP70. Protective effect against cytotoxic effects of hyperthermia was pronounced in the up-regulation of HSP70 (Colson-Proch et al., 2010), in the present study HSP70 up-regulation in marine fish may have a cytoprotective role as a mechanism of survival after exposure to heat stress. Furthermore, Colson-Proch et al. (2010) found that a slight increase in temperature $\left(2^{\circ} \mathrm{C}\right)$ had no effect while more increase $\left(6^{\circ} \mathrm{C}\right)$ lead to thermal stress. From such findings, the increase in water temperature in our results in hot season may be considered the main reason of up-regulation of the HSP70. HSP47 was known as endoplasmic reticulum-resident heat shock protein that proposed to have a vital role as a molecular protein which was essential for post-translation folding of fibril-forming collagens adjusting procollagen chain folding and/or structures (Ojima et al., 2005). In the following study, HSP47 expression was up-regulated more than other genes in Spotted grouper and Seabream collected from Suez Canal compared with other samples collected from Alexandria. A similar increase in HSP47 transcription level was observed in the gonadal cells of rainbow trout (Oncorbynchus mykiss), (Pearson et al., 1996) and zebrafish embryos (Park et al., 2008) subjected to high-temperature squeeze. The activity of antioxidant enzymes have been used to evaluate the response of aquatic organisms under thermal stress (Mueller et al., 2012) and other environmental stressors (Abele et al., 2001; Fasulo et al., 2015; Abdel Gawad et al., 2014; Abdel Gawad et al., 2016; Guerriero et al., 2003; 2004; 2014; Abele et al., 1998). In this regards, we have investigated the effect of heat stress in the hot season which affects the activities of enzymes involved in oxidative metabolism and antioxidant defences in the gills and liver tissues of Spotted grouper and Seabream collected from Suez Canal and Alexandria. The results of the this study showed that the activity levels of GPx and GST were decreased in Spotted grouper and Seabream collected from Suez Canal compared with those collected from Alexandria due to the increase of temperature of water body in Suez Canal compared with the temperature of water body in Alexandria. These findings are in agreement with those of Machado et al. (2014), who reported that heating of temperature influenced the levels and profiles of the antioxidant enzymes as physiological defense and, in particular, the detoxication of electrophile compounds by GST. Taken together, the oxidative stress biomarkers as already reported in Zhao et al. (2017) could be useful tools for assessing the impact of global temperature on global food supply.

\section{CONCLUSIONS}

The main focus of this study was to address possible environmental and food assessment of fishes under climate changes using toxicological markers. The results indicate that the increase in temperature of water body of Suez Canal induced responses affecting the expression of HSP genes and antioxidant enzyme activities as antioxidative defences of Spotted grouper and Seabream during the hot season. Increase of HSP genes expression in marine fish species collected from Suez Canal could be considered as reduced role in prohibiting heat shock transcription factor that may lead to activation of heat-inducible genes and heat acclimation and used as valid biomarker in the food control safeguard the consumers. Thus, warming of water is also likely to alter the composition and abundance of food resources, e.g. fish muscles, available to higher trophic level consumers.

\section{ACKNOWLEDGEMENTS}

This work was supported by the biotechnology and genetic conservation group laboratory, Water Pollution Research Centre of Excellence for Advanced Sciences (CEAS), National Research Centre, Egypt. Deep appreciation for the logistic help of Camilla D'Amato and the experimental direction and participation of the Italian Coordinator of Federico II University, Naples, Italy in the framework of MoU between the National Research Centre of Giza and the Federico II University of Naples, Italy.

\section{Author contributions}

All authors contributed to conception and design of the experiments. All the authors have given their approval to the final version of the manuscript. 


\section{Compliance with ethical standards}

The research described herein was performed on white sea bream (Diplodus sargus) and sardine (Sardine pilchards). This study was conducted in strict accordance with the guidelines of the Ethical Committee, National Research Centre, Egypt on the care and use of animals for scientific purposes.

\section{Conflict of interest}

The authors declare that they have no conflict of interest.

\section{REFERENCES}

Abdel-Gawad, F Kh, Khalil, WKB (2013). Modulation of stressrelated protein genes in the bass (Epinephelus guaza) caught from the Gulf of Suez, the Red Sea, Egypt. Ecotoxicology and Environmental Safety, 96, 175-181.

Abdel-Gawad, F Kh, Guerriero, G, Khalil, WKB, Abbass, HH, (2016). Evaluation of oxidative stress, genotoxicity and gene expression alterations as oil pollution markers in Solea vulgaris, from Suez canal. Quantum Matter, 5, 291-6.

Abdel-Gawad, F Kh, Nassar, HF, Bassem, SM, Guerriero, G, Khalil, WKB (2014). Effect of polycyclic aromatic hydrocarbons (PAHs) on modulate genes encoding stress-related proteins and antioxidant enzymes in different marine fish species of Red Sea Water. World Appl Sci. J, 32(12), 2337-46.

Abele, D, Burlando, B, Viarengo, A, Pörtner, HO (1998). Exposure to elevated temperatures and hydrogen peroxide elicits oxidative stress and antioxidant response in the Antarctic intertidal limpet Nacella concinna. Comp. Biochem. Physiol B, (120), 425-435.

Abele, D, Tesch C, Wencke, P, Pörtner, HO (2001). How do oxidative stress parameters relate to thermal tolerance in the Antarctic bivalve Yoldia eightsi? Antarct Sci, (13), 111-118.

Barnes, JA, Dix, DJ, Collins, BW, Luft, C, Allen, JW (2001). Expression of inducible Hsp70 enhances the proliferation of MCF-7 breast cancer cells and protects against the cytotoxic effects of hyperthermia. Cell Stress Chaperone, 6(4), 316-325.

Bartiromo, A, Guignard, G, Barone Lumaga, MR, Barattolo, F, Chiodini, G, Avino, R, Guerriero, G, Barale, G (2013). The cuticle micromorphology of in situ Erica arborea L. exposed to longterm volcanic gases. Environ Exp Botany, 87, 197-206.

Buckley, BA, Hofmann, GE (2002). Thermal acclimation changes DNA-binding activity of heat shock factor 1(HSF1) in the goby Gillichthys mirabilis: implications for plasticity in the heat shock response in natural populations. J Exp Biol, 205, 3231-3240.

Chen, YM, Kuo, CE, Wang, TY, Shie, PS, Wang, WC, Huang, SL, Tsai, TJ, Chen, PP, Chen, JC, Chen, TY (2010). Cloning of an orangespotted grouper Epinephelus coioides heat shock protein 90AB (HSP90AB) and characterization of its expression in response to nodavirus. Fish Shellfish Immunol, 28(5-6), 895-904.

Copat, C, Brundo, MV, Arena, G, Grasso, A, Oliveri Conti, G, Ledda, C, Fallico, R, Sciacca, S, Ferrante, M (2012). Seasonal variation of bioaccumulation in Engraulis encrasicolus (Linneaus, 1758) and related biomarkers of exposure. Ecotoxicol Environ Saf, 86, 31-7.

Colson-Proch, C, Morales, A, Hervant, F, Konecny, L, Moulin, C, Douady, CJ (2010). First cellular approach of the effects of global warming on groundwater organisms: a study of the HSP70 gene expression. Cell Stress Chaperones 15(3), 259-270.

Dong Y, Dong, S, Ji, T (2008). Effect of different thermal regimes on growth and physiological performance of the sea cucumber Apostichopus japonicus selenka. Aquaculture 275(1-4), 329-334.
Fangue, NA, Hofmeister, M, Schulte, PM (2006). Intraspecific variation in thermal tolerance and heat shock protein gene expression in common killifish, Fundulus heteroclitus. J Exp Biol, 209, 2859-2872.

Fasulo, S, Guerriero, G, Cappello, S, Colasanti, M, Schettino, T, Leonzio, C, Mancini, G, Gornati, R (2015). The "SYSTEMS BIOLOGY" in the study of xenobiotic effects on marine organisms for evaluation of the environmental health status: biotechnological applications for potential recovery. Rev Environ Sci Biotechnol, 14, 339-345.

Guerriero, G, Di Finizio, A, Ciarcia, G (2002). Stress-induced changes in plasma antioxidants of aquacultured sea bass, Dicentrarchus labrax. Comp Biochem Physiol, (132), 205-11.

Guerriero, G, Brundo, MV, Labar, S, Bianchi, AR, Trocchia, S, Rabbito, D, Palumbo, G, Abdel-Gawad, FK, De Maio, A (2017a). Frog (Pelophylax bergeri, Günther 1986) endocrine disruption assessment: characterization and role of skin poly(ADP-ribose) polymerases. Environ. Sci. Pollut. Res. Int. Doi: 10.1007/ s11356-017-0395-9.

Guerriero, G, D’Errico, G, Di Giaimo, R, Rabbito, D, Olanrewaju, OS, Ciarcia, G (2017). Reactive oxygen species and glutathione antioxidants in the testis of the soil biosentinel Podarcis sicula (Rafinesque 1810). Environ Sci Pollut Res. doi: 10.1007/ s11356-017-0098-8.

Guerriero, G, Di Finizio, A, Ciarcia, G (2003). Oxidative Defenses in the Sea Bass, Dicentrarchus labrax. In: Dunn J.F., Swartz H.M. editors. Handbook of Oxygen Transport to Tissue XXIV. Advances in Experimental Medicine and Biology, ed. Springer. vol 530, p. 681-688. doi: 10.1007/978-1-4615-0075-9_68.

Guerriero, G., Ferro, R., Russo, G.L., Ciarcia, G. (2004). Vitamin E in early stages of sea bass (Dicentrarchus labrax) development. Comp Biochem Phys A. 138(4):435-9. doi: 10.1016/j. cbpb.2004.06.003.

Guerriero, G, Prins, GS, Birch, L, Ciarcia, G (2005) Neurodistribution of androgen receptor immunoreactivity in the male frog, Rana esculenta. Ann N Y Acad Sci. 1040:332-336.

Guerriero, G, Trocchia, S, Abdel-Gawad, FKh, Ciarcia, G (2014). Roles of reactive oxygen species in the spermatogenesis regulation. Front Endocrinol (5),56. DOI: 10.3389/fendo.2014.00056.

Habig, WH; Pabst, MJ, Jakoby, WB (1974). Glutathione S-transferases: The first enzymatic step in mercapturic acid formation. Biol. Chem, 249, 7130-7139.

Haslbeck, M, Vierling, E (2015). A first line of stress defence: small heat shock proteins and their function in protein homeostasis. J Mol Biol, 427(7), 1537-1548.

Iwama, GK, Vijayan, MM, Forsyth, RB, Ackerman, PA (1999). Heat shock proteins and physiological stress in fish. Am Zool (39),901-909.

Kregel, KCJ (2002). Heat shock proteins: modifying factors in physiological stress responses and acquired thermotolerance. J Appl Physiol 92(5):2177-2186.

Leach, MD, Budge, S, Walker, L, Munro, C, Cowen, LE, Brown, AJP (2012). Hsp90 orchestrates transcriptional regulation by Hsf1 and cell wall remodelling by MAPK signalling during thermal adaptation in a pathogenic yeast. PLoS ONE, 8(12),e1003069.

Lee, S, Hung, SS, Fangue, NA, Haller, L, Verhille, CE, Zhao, J, Todgham, AE (2016). Effects of feed restriction on the uppertemperature tolerance and heat shock response in juvenile green and white sturgeon. Comp Biochem Physiol A Mol Integr Physiol 198, 87-95. doi: 10.1016/j.cbpa.2016.04.016.

Lewis, M, Götting, M, Anttila, K, Kanerva, M, Prokkola, JM, Seppänen, E, Kolari, I, Nikinmaa, M (2016). Different Relationship between hsp70 mRNA and hsp70 Levels in 
the Heat Shock Response of Two Salmonids with Dissimilar Temperature Preference, 7, 511. collection 2016.

Li, J, Soroka, J, Buchner, J (2012). The Hsp90 chaperone machinery: conformational dynamics and regulation by co-chaperones. Biochim Biophys Acta, 1823(3), 624-635.

Livak, KJ and Schmittgen, TD (2001). Analysis of relative gene expression data using real-time quantitative PCR and the 2$\triangle \triangle C T$ Method. Methods, 25,402-408.

Logan, CA, Buckley, BA (2015). Transcriptomic responses to environmental temperature in eurythermal and stenothermal fishes. J Exp Biol, 218,1915-1924.

Machado, C, Zaleski, T, Rodrigues, E, Carvalho, Cdos, S, Cadena, SM, Gozzi, GJ, Krebsbach, P, Rios, FS, Donatti L. (2014). Effect of temperature acclimation on the liver antioxidant defence system of the Antarctic nototheniids Notothenia coriiceps and Notothenia rossii. Comp Biochem Physiol B Mol Biol. 173;21-8.

Mahanty, A, Purohit, GK, Yadav, RP, Mohanty, S, Mohanty, BP (2017). hsp90 and hsp47 appear to play an important role in minnow Puntius sophomore for surviving in the hot spring run-off aquatic ecosystem. Fish Physiol Biochem, 43(1), 89-102.

Mueller, IA, Devor, DP, Grim, JM, Beers, JM, Crockett, EL, O'Brien, KM (2012). Exposure to critical thermal maxima increases oxidative stress in hearts of white but not red-blooded Antarctic notothenioid fishes. J Exp Biol, (215), 3655-3664.

Muzio, L, Brambilla, V, Calcaterra, L, D’Adamo, P, Martino, G, Benedetti, F (2016) Increased neuroplasticity and hippocampal microglia activation in a mice model of rapid antidepressant treatment. Behav Brain Res, 311, 392-402.

Ojima, N, Yamashita, M, Watabe, S (2005). Quantitative mRNA expression profiling of heat-shock protein families in rainbow trout cells. Biochem Biophys Res Commun, 329(1), 51-57.

Oksala, NKJ, Ekmekc,I, FG, Ozsoy, E, Kirankaya, S, Kokkola, T, Emecen, G, Lappalainen, J, Kaarniranta, K, Atalay, M (2014). Natural thermal adaptation increases heat shock protein levels and decreases oxidative stress. Redox Biol, 3:25-28.

Park, H, Ahn, I-Y, Park, K-I, Hyun, S (2008). Response of antioxidant defence system to thermal stress in the Antarctic clam Laternula elliptica. Antarct. Sci, (20), 521-526.

Pearson, WDS, Kulyk, M, Kelly, GM, Krone, PH (1996). Cloning and characterization of a cDNA encoding the collagen-binding stress protein HSP47 in zebrafish. DNA Cell Biol, 15(3), 263-272.

Pecoraro, R, D'Angelo, D, Filice, S, Scalese, S, Capparucci, F, Marino, F, laria, C, Guerriero, G, Tibullo, D, Scalisi, EM, Salvaggio, A, Nicotera, I and Brundo, MV (2018). Toxicity Evaluation of Graphene Oxide and Titania Loaded Nafion Membranes in Zebrafish. Front Physiol, 8,1039. doi: 10.3389/ fphys.2017.01039.

Pecoraro, R, Marino, F, Salvaggio, A, Capparucci, F, Di Caro, G, Iaria, C, Salvo, A, Rotondo, A, Tibullo, D, Guerriero, G, Scalisi, EM, Zimbone, M, Impellizzeri, G and Brundo, MV (2017). Evaluation of Chronic Nanosilver Toxicity to Adult Zebrafish. Front Physiol, 8,1011. doi: 10.3389/fphys.2017.01011.

Piscopo, M, Notariale, R, Rabbito, D, Ausió, J, Olanrewaju, OS, Guerriero, G (2018) Mytilus galloprovincialis (Lamarck, 1819) spermatozoa: hsp70 expression and protamine-like protein property studies. Environ Sci Pollut Res, doi: 10.1007/s11356-018-1570-9. ahead of print.
Podrabsky, JE, Somero GN (2004). Changes in gene expression associated with acclimation to constant temperatures and fluctuating daily temperatures in an annual killifish Austrofundulus limnaeus. J Exp Biol, 207, 2237-2254.

Puerto, M, Jos, A, Pichardo, S, Gutiérrez-Praena, D, Cameán, AM (2011). Acute effects of pure Cylindrospermopsin on the activity and transcription of antioxidant enzymes in Tilapia (Oreochromis niloticus) exposed by gavage. Ecotoxicology, (20), 1852-1860.

Reddy, DV, Nagbhushanam, P, Ramesh, G (2013). Turnover time of Tural and Rajvadi hot spring waters, Maharashtra, India. Curr Sci, 104(10),1419-1424.

Roberts, R, Agius, C, Saliba, C, Bossier, P, Sung, Y (2010). Heat shock proteins (chaperones) in fish and shellfish and their potential role in relation to fish health: a review. J Fish Dis, 33(10),789-801.

Scalici, M, Traversetti, L, Spani, F, Malafoglia, V, Colamartino, M, Persichini, T, Cappello, S, Mancini, G, Guerriero, G, Colasanti, M (2017). Shell fluctuating asymmetry in the seadwelling benthic bivalve Mytilus galloprovincialis (Lamarck, 1819) as morphological markers to detect environmental chemical contamination. Ecotoxicology, 26, 396. doi:10.1007/ s10646-017-1772-9

Somero, GN (2010). The physiology of climate change: how potentials for acclimatization and genetic adaptation will determine 'winners' and 'losers'. J Exp Biol, (213), 912-920.

Tedeschi, JN, Kennington, WJ, Berry, O, Whiting, S, Meekan, M, Mitchell, NJ (2015). Increased expression of Hsp70 and Hsp90 mRNA as biomarkers of thermal stress in loggerhead turtle embryos (Caretta caretta). J Therm Biol, 47, 42-50.

Tomanek, L (2010). Variation in the heat shock response and its implication for predicting the effect of global climate change on species' biogeographical distribution ranges and metabolic costs. J Exp Biol, 213, 971-979.

Tomanek, L, Somero, GN (2002). Interspecific- and acclimationinduced variation in levels of heat-shock proteins 70 (hsp70) and 90 (hsp90) and heat-shock transcription factor- 1 (HSF1) in congeneric marine snails (genus Tegula): implications for regulation of HSP gene expression. J Exp Biol 205(5):677-685.

Wang, F, Dai, AY, Tao, K, Xiao, Q, Huang, ZL, Gao, M, Li, H, Wang, X Cao, WX, Feng, WL (2015). Heat shock protein-70 neutralizes apoptosis-inducing factor in Bcr/Abl expressing cells., 27(10), 1949-1955.

Wentworth, SA, Thede, K, Aravindabose, V, Monroe, I, Thompson, AW, Molyneaux, N, Owen, CL, Burns, JR, Vicente, AG, Garvin, JL, Packer, RK (2018). Transcriptomic analysis of changes in gene expression of immune proteins of gill tissue in response to low environmental temperature in fathead minnows (Pimephales promelas). Comp Biochem Physiol Part D, 25, 109-117.

Zhao, C, Liu, B, Piao, S, Wang, X, Lobell, DB, Huang, Y, Huang, M, Yao, Y, Bassu, S, Ciais, P, Durand, J-L, Elliott, J, Ewert, F, Janssens, IA, Li, T, Lin, E, Liu, Q, Martre, P, Müller, C, Peng, S, Peñuelas, J, Ruane, AC, Wallach, D, Wang, T, Wu, D, Liu, Z, Zhu, Y, Zhu, Z and Asseng, S (2017). Temperature increase reduces global yields of major crops in four independent estimates. Proc. Natl. Acad. Sci., 114,9326-9331.

Zunino, B, Rubio-Patiño, C, Villa, E, Meynet, O, Proics, E, Cornille, A, Pommier, S, Mondrago'n, L, Chiche, J, Bereder, J-M, Carles, M, Ricci, J-E (2016). Hyperthermic intraperitoneal chemotherapy leads to an anticancer immune response via exposure of cell surface heat shock protein 90 . Oncogene, 35, 261-268. 